\title{
Occurrence of Pesticides and PPCPs in Surface and Drinking Water in Southern Brazil: Data on 4-Year Monitoring
}

\author{
Sergiane S. Caldas, ${ }^{a}$ Jean Lucas $O$. Arias, ${ }^{\circledR a}$ Caroline Rombaldi, ${ }^{a}$ Lucas L. Mello, ${ }^{a}$ \\ Maristela B. R. Cerqueira, ${ }^{a}$ Ayrton F. Martins ${ }^{b}$ and Ednei G. Primel ${ }^{\odot *, a}$ \\ ${ }^{a}$ Laboratório de Análise de Compostos Orgânicos e Metais (LACOM), Escola de Química e Alimentos, \\ Universidade Federal do Rio Grande (FURG), 96203-900 Rio Grande-RS, Brazil \\ ${ }^{b}$ Departamento de Química, Universidade Federal de Santa Maria (UFSM), \\ 97105-900 Santa Maria-RS, Brazil
}

\begin{abstract}
This study evaluated the environmental occurrence of fifty-one pesticides, pharmaceuticals and personal care products (PPCPs) in surface and drinking water samples collected in southern Brazil over a 4-year period. The method used involved a stage based on solid-phase extraction, followed by liquid chromatography tandem mass spectrometry. Thirty compounds were detected (22 different pesticides and 8 PPCPs) and at least four compounds were identified in more than $50 \%$ of the samples. Atrazine was the most frequently detected pesticide and it was found at concentrations between 5 and $49 \mathrm{ng} \mathrm{L}^{-1}$. From PPCPs, glibenclamide, methylparaben and nimesulide were the most commonly detected in both drinking water and surface water samples. Results showed the extent to which traces of pesticides and PPCPs were present in water samples from this region.
\end{abstract}

Keywords: liquid chromatography tandem mass spectrometry, pesticides, pharmaceuticals and personal care products, solid phase extraction, surface and drinking water

\section{Introduction}

Brazil is the world's largest consumer of pesticides and over 1500 commercial products have been registered by the Brazilian Ministry of Agriculture. However, the legal standards governing water quality in Brazil do not cover a number of products that are used routinely, and many emerging contaminants are not listed in the current legislation on the quality of drinking water., ${ }^{1,2}$ Although the country leads the world in terms of the use of pesticides, little is known about their occurrence, and very little data has been obtained with regard to the presence of pharmaceuticals and personal care products (PPCPs) in the environment. ${ }^{3-5}$

Even if the concentration levels found in natural water samples are low (ng L ${ }^{-1}$ or $\mu \mathrm{g} \mathrm{L}^{-1}$ ), some literature points to the possible influence of these contaminants, since they are suspect to increase cancer rates, reproductive impairment in humans and animals, and antimicrobial resistance. ${ }^{6}$ However, because of contradictions in the outcomes of

*e-mail: eprimelfurg@gmail.com some investigations, some authors ${ }^{7}$ have proposed that no significant conclusions regarding the relationship between adverse effects on humans and extents of exposure can be drawn. Although there are still few references about the possible effects to humans, ensuring water quality is a crucial measure for public health and environmental protection.

Residues of pesticides and, more recently, PPCPs, have been detected in aquatic environments (wastewater treatment plants, drinking water, rivers and groundwater) all around the world, ${ }^{8,9}$ including Brazil. ${ }^{3,10,11}$ Some PPCPs that are classified as endocrine disrupting compounds (EDC), which may have human health effects at low concentrations, have also been detected in Brazilian waters, ${ }^{11-14}$ pointing to the importance of this kind of study.

Additionally, in many Brazilian regions, there is a high population density in areas suffering from poor sanitary conditions, which contributes to the polution of rivers and reservoirs that supply water. ${ }^{5}$ As a result, there is an urgent need to investigate the occurrence of emerging contaminants in natural waters in Brazil.

Due to the importance of monitoring the water quality to ensure water for its multiples uses as urban and agricultural 
supply, the aim of this study was to assess the quality of surface and drinking water in the city of Rio Grande, by examining the occurrence of 18 PPCPs and 33 pesticides (Table S1, Supplementary Information (SI) section) through solid phase extraction (SPE) and analytical determination by liquid chromatography with electrospray ionization tandem mass spectrometry (LC-ESI-MS/MS).

The selection of the PPCPs included in this study was based on their broad use in human medicine and hygiene. Moreover, most of these pharmaceuticals are part of the Brazilian list of essential medicines. ${ }^{15}$ Besides, most of the pesticides under investigation are indicated to be used in rice plantation, ${ }^{16}$ which is the main agricultural practice near the sampling area.

\section{Experimental}

\section{Chemical and reagents}

High purity (>90\%) analytical standards of pesticides and PPCPs were purchased from Sigma-Aldrich (São Paulo, Brazil); the list of compounds under analysis is shown in Table S1 (SI section). Individual standard solutions were prepared in methanol at a concentration of $1,000 \mu \mathrm{g} \mathrm{mL}^{-1}$. Working solutions of studied compounds were prepared at concentration level of $100 \mu \mathrm{g} \mathrm{mL}^{-1}$ in methanol. All the solutions were kept in a freezer at $-18^{\circ} \mathrm{C}$. All the solvents used were HPLC grade from Mallinckrodt (Phillipsburg, NJ, USA) and all the other reagents were of analytical grade. Ultrapure water was obtained from a Direct Q UV3 ${ }^{\circledR}$ water purification system (Millipore, Bedford, MA, USA). The SPE extraction tubes were Chromabond C18 EC (octadecyl-modified silica phase) of $500 \mathrm{mg}$ from Macherey-Nagel (Düran, Germany).

\section{Sampling site and sampling collection}

Sampling was carried out monthly at the Companhia Riograndense de Saneamento (CORSAN) (32 $7^{\circ} 8.868^{\prime \prime} \mathrm{S}$, $52^{\circ} 10^{\prime} 44.983$ 'W), from January 2011 to December 2014, totaling forty-eight samples of drinking water and fortyeight samples of surface water.

Samples of drinking and surface water were obtained directly from their sources. The former were collected at the outlet of the treatment plant, at the end of all the treatment stages, while the latter were collected at its entrance in treatment plant. The water under treatment (surface water) comes from the São Gonçalo Channel.

São Gonçalo Channel is about $70 \mathrm{~km}$ long with an average depth of five meters and it is located in the southern of Rio Grande do Sul State, between the cities of
Rio Grande and Pelotas. São Gonçalo Channel connects the Patos Lagoon with the Mirim Lagoon. The Patos-Mirim lagoons are located in the coastal plain of Rio Grande do Sul State (southern Brazil), although part of the Mirim Lagoon is located in Uruguay. These lagoons have a diverse flora and fauna and supports fisheries, agriculture, industry, and municipalities. ${ }^{17}$

The channel is a very important environment, located in a predominantly rural region, and its waters ensure the urban and industrial water supply of the city of Rio Grande, with a population of about 250,000 inhabitants, and will soon supply about $40 \%$ of the city of Pelotas, with 350,000 inhabitants. $^{18}$

The stages carried out in the water treatment station include the pumping from the source, coagulation with aluminum sulfate, flocculation and sedimentation. Afterwards, a filtration step is carried out followed by a disinfection with chlorine and water fluoridation.

Two liters of each sample were collected in an amber glass bottle previously rinsed with acetone and dried at $100{ }^{\circ} \mathrm{C}$. Just before the sampling, the bottles were rinsed with the same water. The samples were stored at $4{ }^{\circ} \mathrm{C}$ until analysis, which was always carried out on the same day that they were collected.

\section{Sample preparation}

Samples (2 L) were divided into two with one liter each due to the diversity of $\mathrm{p} K_{\mathrm{a}}$ values of the target analytes. One of them had the $\mathrm{pH}$ adjusted to 3 (acidified) and the other one had no pH adjustment (non-acidified). After, the samples were filtered $(0.45 \mu \mathrm{m}$ membrane filters $)$ and extracted by SPE in duplicate and injected three times.

\section{Acidified subsamples}

A subsample was acidified to $\mathrm{pH} 3.0$ with phosphoric acid 1:1 (v/v). After that, it was passed through an SPE cartridge, which was previously conditioned with $3 \mathrm{~mL}$ methanol, $3 \mathrm{~mL}$ purified water and $3 \mathrm{~mL} \mathrm{pH} 3.0$ purified water. Following this, the subsamples were mixed and passed through the SPE cartridges at $10 \mathrm{~mL} \mathrm{~min}^{-1}$. Then, the cartridges were air-dried for $10 \mathrm{~min}$. The analytes were eluted with $2 \mathrm{~mL}(1+1 \mathrm{~mL})$ methanol. The final organic extracts were directly analyzed by LC-ESI-MS/MS.

\section{Non-acidified subsamples}

The $\mathrm{pH}$ of non-acidified drinking and surface water subsamples was measured in each sampling procedure; the values ranged from 6.4 to 7.8. The SPE cartridge was conditioned with $6 \mathrm{~mL}$ methanol and $6 \mathrm{~mL}$ purified water. 

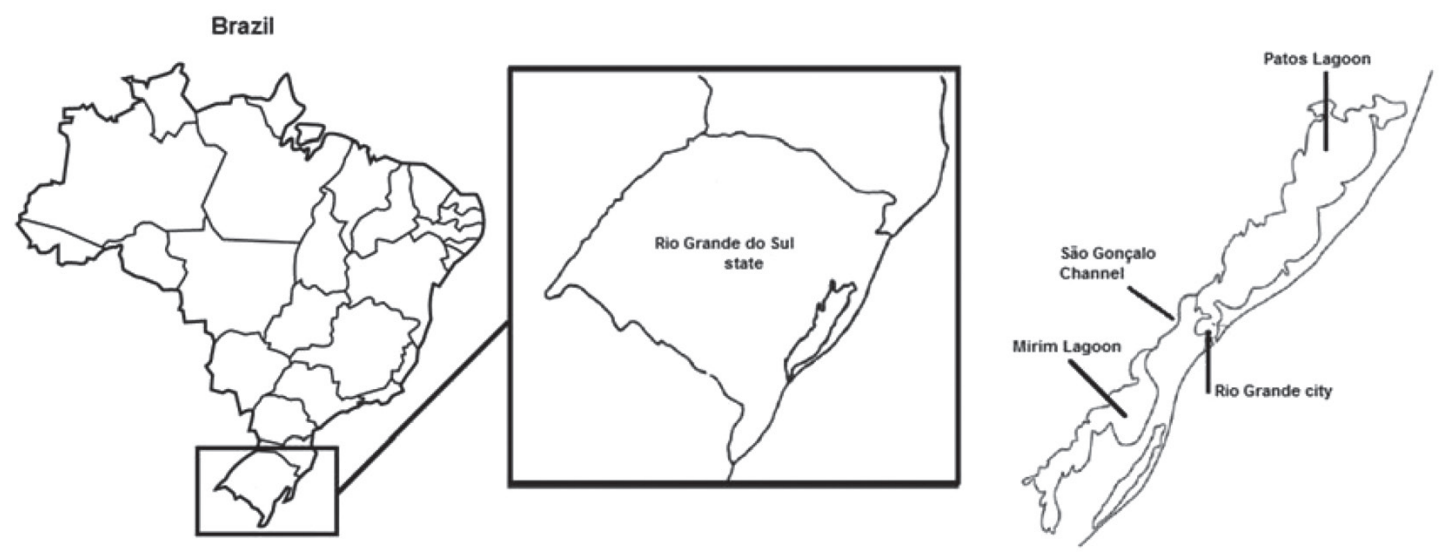

Figure 1. Area of study, located in the city of Rio Grande, State of Rio Grande do Sul, Brazil.

After that, the subsamples were mixed and passed through the SPE cartridges at $10 \mathrm{~mL} \mathrm{~min}^{-1}$. Then, the cartridges were air-dried for $10 \mathrm{~min}$. The analytes were eluted with $2 \mathrm{~mL}(1+1 \mathrm{~mL})$ methanol. The final organic extracts were directly analyzed by LC-ESI-MS/MS.

\section{LC-ESI-MS/MS}

The analyses were conducted with the aid of a Waters Alliance 2695 Separations Module HPLC, equipped with a quaternary pump, an automatic injector, and a thermostated column compartment (Waters, Milford, MA, USA). The chromatographic separation was carried out with a Kinetex C8 $(50 \times 3.0 \mathrm{~mm}$ i.d., $2.6 \mu \mathrm{m}$ size particle) Phenomenex column (Torrance, CA, USA). The mobile phase components are: (A) ultrapure water with $0.1 \%$ acetic acid and (B) pure methanol, with elution in gradient mode. The initial composition was $20 \% \mathrm{~B}$, which increased linearly to $90 \%$ in $20 \mathrm{~min}$, maintained this level until $23 \mathrm{~min}$ and, then, returned to the initial composition (20\% B) in $0.5 \mathrm{~min}$, where it remained for $6.5 \mathrm{~min}$. The injection volume was $10 \mu \mathrm{L}$.

A Quattro micro API (triple quadrupole) mass spectrometer was used, equipped with a Z-spray electrospray Micromass ionization source (Waters, Milford, MA, USA). Both the drying and nebulizing gas were nitrogen, generated from pressurized air by a Genius NM32LA nitrogen generator (Peak Scientific, Netherlands). The nebulizer gas flow was set to $50 \mathrm{~L} \mathrm{~h}^{-1}$, while the desolvation gas flow rate was set to $450 \mathrm{~L} \mathrm{~h}^{-1}$. When operating in the selected reaction monitoring (SRM) mode, the collision gas was argon 5.0 (White Martins, Sapucaia do Sul, Brazil) with pressure of $3.5 \times 10^{-3} \mathrm{mbar}$ in the collision cell. The optimized values were as follows: capillary voltage, $4.5 \mathrm{kV}$; extractor voltage, $2 \mathrm{~V}$; source temperature, $100{ }^{\circ} \mathrm{C}$; desolvation temperature, $450{ }^{\circ} \mathrm{C}$; and multiplier, $650 \mathrm{~V}$. The analytical instrument control, data acquisition and treatment were carried out with the aid of MassLynx ${ }^{\circledR}$ software, version 4.1 (Micromass, Manchester, UK). Data on SRM transitions, cone voltage and collision energy are shown in Table S1 (SI section), as well as the limits of quantification (LOQs) required for the method.

\section{Quality control}

Calibration curves were prepared to cover concentrations within the range between the LOQ for each compound under study and $1,000 \mu \mathrm{g} \mathrm{L}^{-1}$. Regression coefficients were considered acceptable when higher than 0.99 . The accuracy of the method was determined in advance. ${ }^{10}$ Recoveries ranged from 49 to $132 \%$ for PPCPs and pesticides with relative standard deviation (RSD) values lower than $20 \%$. These values were suitable for the extraction of a series of compounds belonging to several chemical classes.

In view of the complexity of analyzing compounds in trace concentrations caused by background contamination, they were continuously checked by analyzing extraction solvents and blank samples, as well as applying a quality control to each batch extraction.

Atrazine- $d_{5}$ was added as surrogate to find out the accuracy of the method during the quantification of the analytes in the water samples.

To guarantee the reliable identification and confirmation, some parameters were considered. Retention time of the analyte in the extract should correspond to that of the calibration standard with a tolerance of $\pm 0.1 \mathrm{~min}$. Moreover, whenever it was possible, two product ions were analyzed. ${ }^{19}$

Besides, during the method applicability, the relative ratios of selective ions, expressed as a ratio relative to the most intense ion and the second most intense, were evaluated for all detected compounds. The ion ratio should not deviate more than $30 \%$ (relative). ${ }^{19}$ 


\section{Results and Discussion}

\section{Distribution of pesticides and PPCPs in water samples}

\section{Pesticides}

A larger number of pesticides were detected than PPCPs (Table 1).

In the sampling period, atrazine was detected in more than $50 \%$ of the samplings, at concentrations ranging from
5 to $49 \mathrm{ng} \mathrm{L}^{-1}$ in surface water and from 5 to $37 \mathrm{ng} \mathrm{L}^{-1}$ in drinking water. Atrazine is an herbicide from the class of triazines, which is mainly employed in Brazil as a weedkiller in the cultivation of rice, soybeans, sugarcane, corn and other crops. ${ }^{20}$ Several other studies have also detected atrazine in water samples. ${ }^{21,22}$ Concentrations up to $433.9 \mathrm{ng} \mathrm{L}^{-1}$ were detected in river waters in Argentina ${ }^{23}$ and from 9.3 to $81 \mathrm{ng} \mathrm{L}^{-1}$ in Brazil. ${ }^{24}$ Atrazine has been listed by the United States Environmental Protection Agency

Table 1. Summary of pesticides and PPCPs detected in surface and drinking water $(n=48)$

\begin{tabular}{|c|c|c|c|c|c|c|c|c|c|c|c|}
\hline & \multirow{2}{*}{$\begin{array}{c}\text { LOQ / } \\
\left(\mathrm{ng} \mathrm{L}^{-1}\right)\end{array}$} & \multicolumn{5}{|c|}{ Surface water } & \multicolumn{5}{|c|}{ Drinking water } \\
\hline & & $\mathrm{n}<\mathrm{LOQ}$ & $\mathrm{n}>\mathrm{LOQ}$ & $\begin{array}{c}\operatorname{Min} / \\
\left(\mathrm{ng} \mathrm{L}^{-1}\right)\end{array}$ & $\begin{array}{c}\operatorname{Max} / \\
\left(\operatorname{ng~L}^{-1}\right)\end{array}$ & $\begin{array}{l}\text { Mean / } \\
\left(\mathrm{ng} \mathrm{L}^{-1}\right)\end{array}$ & $\mathrm{n}<\mathrm{LOQ}$ & $\mathrm{n}>\mathrm{LOQ}$ & $\begin{array}{c}\operatorname{Min} / \\
\left(\mathrm{ng} \mathrm{L}^{-1}\right)\end{array}$ & $\begin{array}{c}\operatorname{Max} / \\
\left(\operatorname{ng~L}^{-1}\right)\end{array}$ & $\begin{array}{l}\text { Mean / } \\
\left(\operatorname{ng~L}^{-1}\right)\end{array}$ \\
\hline \multicolumn{12}{|c|}{ Pesticide } \\
\hline Atrazine & 4 & 2 & 25 & 5 & 49 & 19 & 4 & 19 & 5 & 37 & 16 \\
\hline Azoxystrobin & 40 & 11 & 8 & 41 & 233 & 86 & 10 & 3 & 100 & 192 & 131 \\
\hline Bentazone & 8 & 12 & 0 & 24 & 36 & 30 & 1 & 1 & 30 & 30 & 30 \\
\hline Carbendazin & 8 & 9 & 9 & 10 & 42 & 24 & 0 & 0 & - & - & - \\
\hline Carbofuran & 8 & 9 & 8 & 10 & 200 & 71 & 8 & 5 & 20 & 50 & 42 \\
\hline Cyproconazole & 8 & 6 & 3 & 13 & 14 & 13 & 7 & 3 & 10 & 14 & 12 \\
\hline Clomazone & 40 & 19 & 8 & 50 & 124 & 76 & 16 & 9 & 40 & 164 & 74 \\
\hline Diuron & 40 & 20 & 3 & 50 & 790 & 300 & 14 & 2 & 40 & 490 & 200 \\
\hline Difenoconazole & 8 & 2 & 1 & 15 & 15 & 15 & 2 & 0 & - & - & - \\
\hline Epoxiconazole & 40 & 15 & 1 & 40 & 40 & 40 & 13 & 2 & 70 & 70 & 70 \\
\hline Fipronil & 0.8 & 1 & 2 & 6 & 21 & 14 & 0 & 0 & - & - & - \\
\hline Imazapic & 8 & 0 & 1 & 77 & 77 & 77 & 3 & 5 & 12 & 15 & 14 \\
\hline Imazethapyr & 8 & 0 & 1 & 25 & 25 & 25 & 2 & 7 & 12 & 37 & 23 \\
\hline Iprodione & 40 & 1 & 2 & 800 & 1000 & 900 & 3 & 0 & - & - & - \\
\hline Irgarol & 4 & 9 & 3 & 4 & 10 & 8 & 9 & 1 & 4 & 4 & 4 \\
\hline Pyrazosulfuron-ethyl & 4 & 0 & 1 & 13 & 13 & 13 & 0 & 0 & - & - & - \\
\hline Propanil & 8 & 0 & 2 & 19 & 20 & 20 & 0 & 1 & 10 & 10 & 10 \\
\hline Propiconazole & 4 & 1 & 0 & - & - & - & 0 & 0 & - & - & - \\
\hline Quinclorac & 80 & 1 & 4 & 20 & 288 & 168 & 2 & 3 & 124 & 248 & 182 \\
\hline Simazine & 4 & 0 & 1 & 900 & 900 & 900 & 1 & 0 & - & - & - \\
\hline Tebuconazole & 40 & 25 & 16 & 40 & 300 & 123 & 18 & 22 & 40 & 460 & 134 \\
\hline Trifloxystrobin & 8 & 4 & 0 & - & - & - & 4 & 2 & - & - & 303 \\
\hline \multicolumn{12}{|c|}{ PPCP } \\
\hline Avobenzone & 40 & 1 & 1 & 340 & 340 & 340 & 0 & 1 & 290 & 290 & 290 \\
\hline Caffeine & 40 & 8 & 0 & - & - & - & 2 & 0 & - & - & - \\
\hline Glibenclamide & 40 & 3 & 4 & 50 & 120 & 91 & 1 & 0 & - & - & - \\
\hline Methylparaben & 8 & 14 & 9 & 15 & 840 & 262 & 6 & 1 & 234 & 234 & 234 \\
\hline Nimesulide & 4 & 1 & 6 & 70 & 730 & 238 & 1 & 1 & 181 & 181 & 181 \\
\hline Propylparaben & 8 & 0 & 4 & 90 & 190 & 115 & 0 & 0 & - & - & - \\
\hline Triclocarban & 0.8 & 1 & 0 & - & - & - & 1 & 0 & - & - & - \\
\hline Triclosan & 80 & 1 & 0 & - & - & - & 0 & 0 & - & - & - \\
\hline
\end{tabular}

$\mathrm{n}<$ LOQ: number of samples detected below the LOQ (these data not include the samples with concentrations below the LOD); $\mathrm{n}>\mathrm{LOQ}$ : number of samples detected above the LOQ; Min: minimum; Max: maximum; Mean: mean concentrations for each compound. 
(US EPA) as a pesticide with restricted use, because of its persistence in water and various adverse health effects it has on humans. ${ }^{25}$ Moreover, some studies ${ }^{20}$ have pointed out that it has undesirable effects, mainly in aquatic environments, due to its great solubility in water.

The fungicide azoxystrobin was also detected in concentrations that varied from 41 to $233 \mathrm{ng} \mathrm{L}^{-1}$, and from 100 to $192 \mathrm{ng} \mathrm{L}^{-1}$ in surface and drinking water, respectively. The application of this compound is allowed for some crops, such as rice and onions, which are cultivated in the region of this study, a fact that makes it more likely to be detected in water samples. Azoxystrobin was also detected in $80 \%$ of the samples collected in an estuary in California. ${ }^{26}$ The concentrations found in this study are below the maximum acceptable concentration-environmental quality standard (MAC-EQS) of $1800 \mathrm{ng} \mathrm{L}^{-1}$, which protect aquatic organisms from acute and chronic effects. ${ }^{27}$

Cyproconazole, difenoconazole, epoxiconazole, propiconazole and tebuconazole were in a concentration range from LOQ to $460 \mathrm{ng} \mathrm{L}^{-1}$. Azole compounds, such as triazoles and imidazoles, have been largely used as fungicides in agriculture, biocides in various products, and antifungal agents in human and veterinary pharmaceuticals. $^{28}$

Tebuconazole was detected in more than $80 \%$ of the samples, both in drinking and surface water, as shown in Table 1. Tebuconazole occurs at relatively high concentrations (up to $460 \mathrm{ng} \mathrm{L}^{-1}$ ), which can be explained by its broad-spectrum systemic action which can be used as a foliar spray or seed-dressing in a diversity of cultures. Another important aspect of tebuconazole is the low elimination during the procedures currently being followed in the wastewater treatment plant. Loads determined in untreated and treated wastewater indicated that some azoles, including tebuconazole, were largely unaffected by wastewater treatment. ${ }^{28}$ Other studies detected tebuconazole in river water $\left(3 \mathrm{ng} \mathrm{L}^{-1}\right)$ and treated wastewater $\left(2 \mathrm{ng} \mathrm{L}^{-1}\right),{ }^{29}$ groundwater (from 0.2 up to $\left.3.65 \mu \mathrm{g} \mathrm{L}^{-1}\right),{ }^{30}$ surface water (6.2 up to $\left.41.1 \mathrm{ng} \mathrm{L}^{-1}\right)^{21}$ and sludge from the drinking water treatment plant (below $\left.7.5 \mu \mathrm{g} \mathrm{kg}^{-1}\right){ }^{31}$

Some studies have indicated that tebuconazole can affect morphological parameters and cholinergic signaling by inhibiting acetylcholinesterase in larvae and adult zebrafish, ${ }^{32}$ and common carp (Cyprinus carpio) health is adversely affected by exposure to tebuconazole, compromising its survival in the natural environment. ${ }^{33}$

The herbicide clomazone was detected in more than $50 \%$ of the samples, at concentrations ranging from below LOQ to $164 \mathrm{ng} \mathrm{L}^{-1}$, and with average concentrations of 73.8 and $75.5 \mathrm{ng} \mathrm{L}^{-1}$ in drinking and surface water, respectively. Caldas et al. ${ }^{10}$ found higher concentrations of clomazone in drinking water than in surface water and estimated that there was an average concentration of $63.3 \mathrm{ng} \mathrm{L}^{-1}$ in the water supply and $46.9 \mathrm{ng} \mathrm{L}^{-1}$ in surface water. Moreover, this compound has often been found in studies carried out in southern Brazil, where it is commonly detected in water samples because of the widespread use of this herbicide in the region. ${ }^{34}$

Diuron was detected in $50 \%$ of the surface water samples and in $35 \%$ of the drinking water samples. Diuron is an herbicide which belongs to the phenylamide family (subclass phenylurea) and represents an important class of contact herbicides that have been used worldwide for more than 40 years. In the region under study, diuron is applied to crops such as fruit, cotton, sugar cane and wheat, mainly on family farms, where it is said to be used to prepare the land before planting. On the other hand, marine navigation is another very common regional activity, and diuron is used in anti-fouling paints. ${ }^{35}$ Diuron was detected in Mediterranean coastal waters in more than $77 \%$ of the samples, within the concentration range of 1-222 $\mathrm{ng} \mathrm{g}^{-1}$ of polar organic contaminant integrative samplers (POCIS) sorbent ${ }^{36}$ in Brazilian surface waters within the range of 7-123.5 $\mathrm{ng} \mathrm{L}^{-1} ;{ }^{10}$ and in Spanish groundwater it was detected in more than $50 \%$ of the samples below the LOQ up to $178 \mathrm{ng} \mathrm{L}^{-1} \cdot{ }^{37}$

Irgarol was detected in a range from 4 to $10 \mathrm{ng} \mathrm{L}^{-1}$ in surface water and at $4 \mathrm{ng} \mathrm{L}^{-1}$ in drinking water. It is an effective photosynthesis inhibitor; its very low water solubility makes it very useful in long-life antifouling coatings for marine applications (to prevent algae from growing). The low levels of irgarol detected in this study can be explained by the great distance from the coastal zones to the sampling sites. Irgarol is also the most widely detected anti-fouling agent in the world and predominantly occurs in ports and coastal areas. Studies ${ }^{38}$ carried out in the USA, Europe and Asia have shown relatively high concentrations of irgarol in water samples, in the range from 1300 to $4200 \mathrm{ng} \mathrm{L}^{-1}$.

Although irgarol and diuron are used in antifouling paints, diuron is also used in agriculture as an herbicide, which could justify its higher and most frequently occurrence than irgarol. Besides, diuron has relatively low octanol-water $\left(\log \mathrm{K}_{\mathrm{ow}}=2.87\right)$, which indicates a low tendency for retention in sediment and high water mobility. ${ }^{39}$

The imidazolinone class deserves a closer look, in particular imazapic and imazethapyr, which are able to control weeds in rice farming. Both are used in irrigation systems, which are common in this region, and believed to 
be responsible for high levels of productivity. Owing to the irrigation and the high water solubility (in the order of $\mathrm{g} \mathrm{L}^{-1}$ ), they are susceptible to leaching and can thus be detected in water samples. ${ }^{40}$ In this study, both were detected in concentrations higher than the LOQ. Imazapic was detected between 12 and $15 \mathrm{ng} \mathrm{L}^{-1}$, whereas imazethapyr between 12 and $37 \mathrm{ng} \mathrm{L}^{-1}$.

The acute toxicity of the mixture of imazethapyr and imazapic was studied using a fish species as a bioindicator and the results indicated that the formulation had a potential toxic effect on parameters of hematology, biochemistry, immunology, ionoregulation and enzymology. ${ }^{41}$

The herbicide quinclorac was found at relatively high concentrations, i.e., $217.3 \mathrm{ng} \mathrm{L}^{-1}$ in surface water and $182.3 \mathrm{ng} \mathrm{L}^{-1}$ in drinking water on average, although only in a few samples. It is mainly recommended for the control of weeds in rice plantations, which are quite common in the region, a fact that may explain why this compound is found in high concentrations. Quinclorac were found in four out of twenty six samples in Uruguay, with an average between 2,000 and 4,000 $\mathrm{ng} \mathrm{L}^{-1} .{ }^{42}$

Other pesticides, i.e., bentazone, carbendazim, iprodione, propanil, simazine and trifloxystrobin, were also detected, although, in most cases, at concentrations below the LOQ. Some studies reported the occurrence of these compounds in water samples. Chen et al. ${ }^{43}$ detected carbendazim in water samples in the range of $n g \mathrm{~L}^{-1}$. Hurtado-Sanchez et al. ${ }^{44}$ detected simazine below the LOQ in surface waters. Huntscha et al. ${ }^{45}$ detected bentazone below the LOQ and carbendazim and simazine in water samples in the order of $n g \mathrm{~L}^{-1}$.

The pesticides found in this study are indicated to rice cultivation, showing that this agricultural practice could have influence in this environment. Some studies have also reported the influence of activities of agricultural origin in the quality of São Gonçalo waters. ${ }^{21,46,47}$ Rice culture is recognized to be an activity with a high potential to contaminate water sources because it may transport chemical inputs, excess nutrients and sediment supply due to leaching from the crop. ${ }^{46}$

Concentrations of pesticides detected in this study are below those recommended by the guidelines for drinking-water quality laid down by the World Health Organization (Table S1, SI section) and also below the maximum residue limit (MRL) established by the Brazilian legislation. ${ }^{1,2}$ Considering the values established by the European Union for individual pesticides in drinking water of $100 \mathrm{ng} \mathrm{L}^{-1},{ }^{48}$ the maximum values detected of azoxystrobin, cyproconazole, clomazone, quinclorac and tebuconazole exceeded this value. Besides, some of the detected compounds, as atrazine, diuron and simazine were identified as priority substances amongst those that pose a significant risk to the aquatic environment. ${ }^{49}$

Concentrations detected in this study (range from 0.004 to $1 \mu \mathrm{g} \mathrm{L}^{-1}$ ) are in the same range to what have been detected in Brazilian waters. Data related to 17 papers (from 1998 to 2013) referring to pesticides determination in water sampling in Brazil were recently discussed.$^{50}$ Results about the states of Mato Grosso (MT), Rio de Janeiro (RJ), Rio Grande do Sul (RS), São Paulo (SP) and Sergipe (SE) presented results for pesticides contamination in water sample that ranged from 0.002 to $26.2 \mu \mathrm{g} \mathrm{\textrm {L } ^ { - 1 }} .^{50}$

SRM chromatograms of a $5 \mu \mathrm{g} \mathrm{L}^{-1}$ standard solution, blank of the extraction and a positive sample of methylparaben, atrazine and tebuconazole are presented in Figure 2. (a)
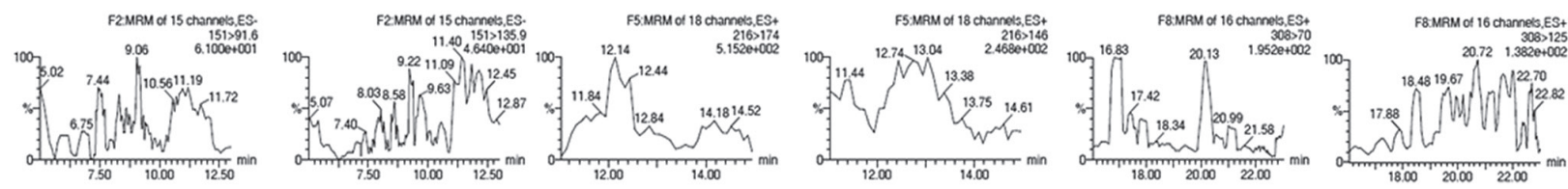

(b)
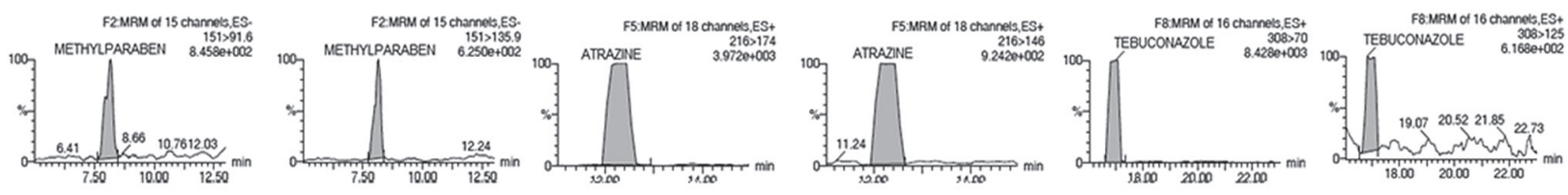

(c)
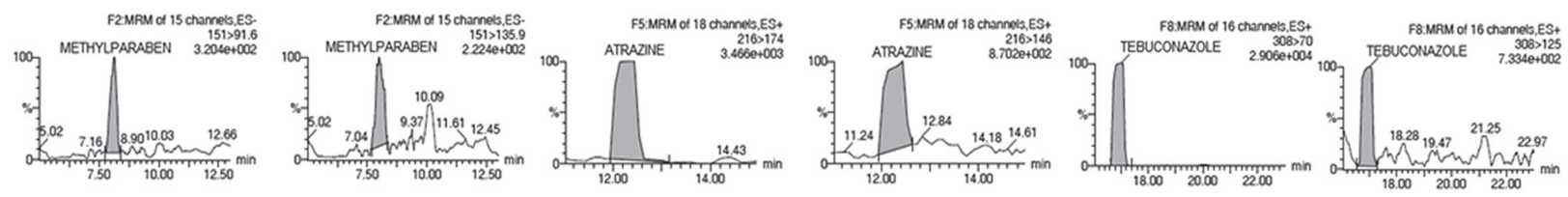

Figure 2. SRM chromatogram of (a) blank sample; (b) $5 \mu \mathrm{g} \mathrm{L} \mathrm{L}^{-1}$ standard solution; (c) positive sample of methylparaben, atrazine and tebuconazole. 


\section{PPCPs}

Glibenclamide, methylparaben and nimesulide were the most commonly detected PPCPs in both drinking and surface water samples. Other PPCPs, such as caffeine, diclofenac, eusolex 6300, propylparaben and triclocarban were also detected, but usually below the LOQ.

The origin of PPCPs seems to be related to some domestic sewage, since the pharmaceuticals that were detected are consumed by humans (caffeine, glibenclamide, nimesulide and diclofenac) and the personal care products are used as preservatives (parabens), antifungals (triclocarban) or UV filter (eusolex 6300). Thus, the presence of these PPCPs seems not to be related to farmland use.

Although caffeine was detected at concentrations lower than $40 \mathrm{ng} \mathrm{L}^{-1}$, it is believed to be one of the primary indicators of anthropogenic contamination. It might be possible to attribute its presence to the discharge of sewage into the watershed. Since it is one of the most widely consumed substances, its occurrence is a clear indication of contamination. ${ }^{51}$

Glibenclamide is a sulfonylurea pharmaceutical largely used for the treatment of type II and gestational diabetes mellitus. ${ }^{52}$ It is one of the drugs distributed free of charge by the Brazilian government. One of the few studies ${ }^{53}$ on the occurrence of glibenclamide in river water detected it at concentrations of $2 \mathrm{ng} \mathrm{L}^{-1}$ by SPE and LC-ESI-MS/MS. In our study, glibenclamide was found in concentrations ranging from 50 to $120 \mathrm{ng} \mathrm{L}^{-1}$.

Alkyl esters of 4-hydroxybenzoic acid represent an important class of preservatives, called parabens, which are widely used in food, cosmetics and pharmaceuticals, due to their antimicrobial activity, limited toxicity and low cost. Parabens are chemical constituents of shampoos, moisturizers, deodorants, perfumes, shaving gels, toothpaste and other products for personal use. ${ }^{10}$ This study evaluated the occurrence of methylparaben and propylparaben. Methylparaben was detected at concentrations ranging from 15 up to $840 \mathrm{ng} \mathrm{L}^{-1}$, whereas propylparaben was from 90 to $190 \mathrm{ng} \mathrm{L}^{-1}$. This class of contaminants was very often detected in aqueous samples at relatively high concentrations..$^{54,55}$ Parabens were determined in samples of tap water (influent and effluent) and methylparaben was detected in tap water at concentrations of $17 \mathrm{ng} \mathrm{L}^{-1}$ and below the LOQ in other samples. ${ }^{56}$ In other study, ${ }^{57}$ parabens were also found in rivers, effluent and influent wastewater. As expected, the levels of parabens in river water were considerably lower than in residual waters. Methylparaben and propylparaben were detected in concentrations below the LOQ in river waters; besides, in sewage water, the relatively high concentrations decrease during the treatment process. The authors ${ }^{57}$ observed a reduction in the concentration of methylparaben from $4427 \mathrm{ng} \mathrm{L}^{-1}$ to below the LOQ and pointed out that parabens were removed in the sewage treatment. Although they did not provide an exhaustive study, they drew attention to their removal tendency.

The acute and chronic toxicity of parabens has been investigated by some studies, and an effect was only found at concentrations higher than those detected by this study..$^{58}$ A review ${ }^{59}$ that evaluated health factors and acute toxicity in animals suggests that methylparaben is practically nontoxic in both oral and parenteral routes and, in a population with 'normal skin', it is practically non-irritating and non-sensitizing. Another study of fish showed that butyl-, propyl- and ethylparaben are shown to be oestrogenic in vivo. Oestrogenicity and toxicity both occurred in a dosing interval between 100 and $300 \mathrm{mg} \mathrm{kg}^{-1} .{ }^{60}$

Nimesulide was detected at concentrations between 70 and $730 \mathrm{ng} \mathrm{L}^{-1}$. Nimesulide is a non-steroidal, antiinflammatory and relatively new drug with analgesic and antipyretic properties. ${ }^{52}$ Owing to the concerns over its safety profile, its use has been banned in several countries, such as the USA, Canada, Australia, Spain, Finland and Ireland since 2007, but it is still used in $3 \%$ gel formulations. ${ }^{61}$ In Brazil, nimesulide is a widely prescribed drug because it has greater efficacy than ibuprofen, diclofenac and pyroxicam; it is among the top ten best-selling medicines. ${ }^{62}$ Nimesulide was detected in surface water samples at concentrations of $12 \mathrm{ng} \mathrm{L}^{-1},{ }^{10}$ a relatively low value compared with those found by this study. In southern Brazil, nimesulide has also been detected in concentrations ranging from 10 to $50 \mathrm{ng} \mathrm{L}^{-1}$.52 In Greece, wastewater samples were analyzed, and nimesulide was detected in influents up to $3581 \mathrm{ng} \mathrm{L}^{-1}$, and effluents up to $9731 \mathrm{ng} \mathrm{L}^{-1}$. Authors attribute these high concentrations to the fact that most of them can be purchased without a prescription. ${ }^{63}$

In a general way, PPCPs have been detected in Brazilian waters in a wide range of concentration, from few $\mathrm{n} \mathrm{L}^{-1}$ to $\mu \mathrm{L} \mathrm{L}^{-1} .{ }^{5}$ Thus, results found in this study agree with previous published papers. ${ }^{5}$

\section{Seasonal variations}

Some studies reported that the concentrations of PPCPs and pesticides are subject to seasonal variations. ${ }^{63,64}$ In this study, the measured concentrations of PPCPs and pesticides in surface waters in the four seasons were compared so that the seasonal pattern could be examined (Figure 3).

In 2011, summer was the season where there was a relatively lower impact in terms of target contaminants, but 2012, 2013 and 2014 had the highest concentration 


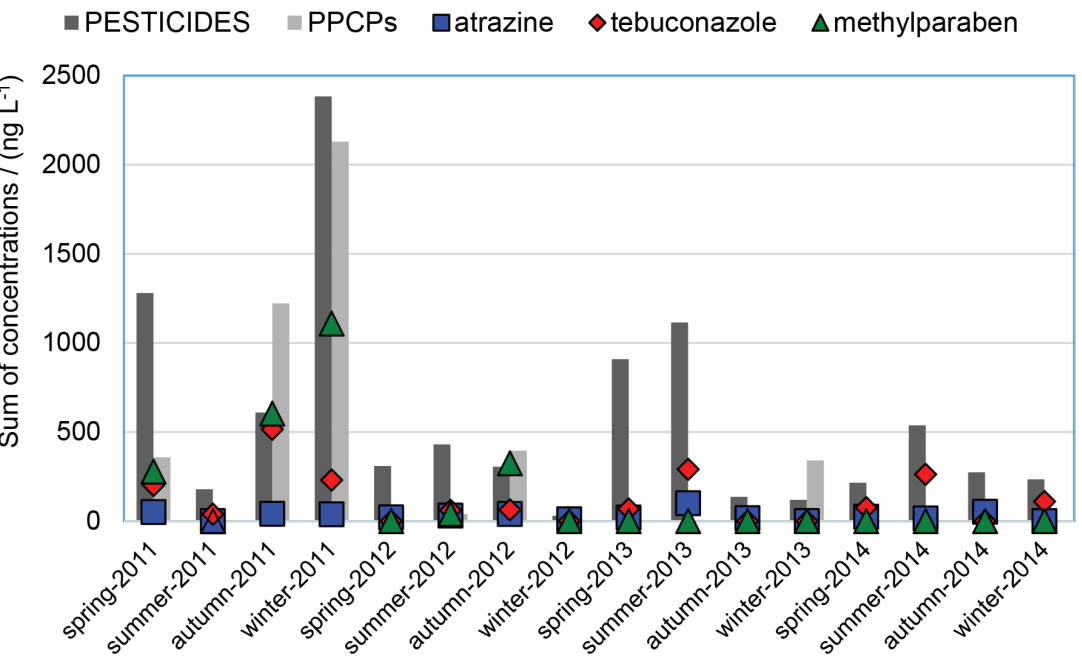

Figure 3. Seasonal variation of the sum of detected concentrations in surface waters of pesticides and PPCPs (bars), and the most detected pesticides: atrazine (blue square) and tebuconazole (red diamond); and PPCPs: methylparaben (green triangle).

of pesticides. However, in all the seasons of the 4-year monitoring period, pesticides were clearly detected in concentrations higher than the LOQ.

The most widely detected compounds were tebuconazole, which was always quantified in summer in the 4-year study, and atrazine, which was always detected in autumn.

As can be observed in Figure 3, high concentrations of pesticides in some seasons were usually related to the detection of tebuconazole. However, in some seasons, other compounds have mostly influenced the detected levels: spring 2011 (simazine, $900 \mathrm{ng} \mathrm{L}^{-1}$ ), winter 2011 (iprodione, $1800 \mathrm{ng} \mathrm{L}^{-1}$ ), spring 2012 (quinclorac, $288 \mathrm{ng} \mathrm{L}^{-1}$ ), summer 2012 (azoxystrobin, $180 \mathrm{ng} \mathrm{L}^{-1}$ ) and spring 2013 (diuron, $\left.790 \mathrm{ng} \mathrm{L}^{-1}\right)$.

Higher levels of PPCPs seem to be mostly related to the presence of methylparaben, with exception of winter 2013 (avobenzone, $340 \mathrm{ng} \mathrm{L}^{-1}$ ).

PPCPs are usually detected at concentrations lower than those of pesticides, and, most often, at concentrations lower than the LOQ.

\section{Conclusions}

The levels of pesticides and PPCPs detected in surface and drinking water samples ranged from a few ng $\mathrm{L}^{-1}$ to few hundred $n g \mathrm{~L}^{-1}$. Thirty compounds were detected (22 different pesticides and 8 PPCPs) and at least four compounds were identified in more than $50 \%$ of the samples.

With regard to the target PPCPs, methylparaben was the contaminant that was most often detected, but others, such as caffeine, glibenclamide and nimesulide, which belong to different therapeutic categories, were also detected.
Likewise, the presence of a wide range of pesticides was observed in the whole 4-year monitoring period. Pesticides of classes such as triazines, triazoles, carbamates, strobilurins and imidazolinones, were detected.

Although low concentration of pesticides and PPPCs were detected in samples, results show that they are present and the environment is exposed to a lot of different compounds that can have different effects on biota. Besides, little is known about the symbiotic effect of the simultaneously exposition to a different compounds.

These findings confirm the vulnerability of these waters to pesticide contamination and motivate currently ongoing studies to evaluate the influence of farming practices on the fate of pesticides, aiming to minimize the impact of these compounds in agricultural areas.

Besides, São Gonçalo water quality should be monitored since this reservoir enables the cultivation of rice, supports several communities of artisanal fishermen and supply water for Rio Grande City.

It is hoped that the results of this study will draw attention to the serious consequences of the presence of pesticide and PPCPs residues in natural waters, the potential health hazard to the public and damage to the environment.

The use of pesticides should be avoided or minimized, and when necessary, good agricultural practices should be respected. Besides, related to the PPCPs, all sewage should be treated before disposition in the environment, since many compounds can be eliminated or have their concentrations decreased after treatment.

\section{Supplementary Information}

Supplementary data are available free of charge at http://jbcs.sbq.org.br as PDF file. 


\section{Acknowledgments}

The authors are grateful for the financial support and fellowships granted by the Brazilian agencies FAPERGS (17/2551-0000966-5), CNPq, CAPES and FINEP. E. G. Primel was awarded a productivity research fellowship by the Brazilian Government Agency CNPq (DT 311694/2016-0). Special thanks to CORSAN for supplying the water samples.

\section{References}

1. Ministério da Saúde; Portaria No. 2.914 de 12 de dezembro de 2011; Dispõe sobre os Procedimentos de Controle e de Vigilância da Qualidade da Água para Consumo Humano e Seu Padrão de Potabilidade; Ministério da Saúde: Brasília, 2011. Available at http://bvsms.saude.gov.br/bvs/saudelegis/ gm/2011/prt2914_12_12_2011.html, accessed in August 2018.

2. Conselho Nacional de Meio Ambiente (CONAMA); Resolução No. 357, de 17 de Março de 2005; Dispõe sobre a Classificação dos Corpos de Água e Diretrizes Ambientais para o Seu Enquadramento, bem como Estabelece as Condições e Padrões de Lançamento de Efluentes, e Dá Outras Providências; Diário Oficial da União: Brasília, 2005. Available at http://www.mma.gov. br/port/conama/res/res05/res35705.pdf, accessed in August 2018.

3. Montagner, C. C.; Vidal, C.; Acayaba, R. D.; Jardim, W. F.; Jardim, I. C.; Umbuzeiro, G. A.; Anal. Methods 2014, 6, 6668.

4. Marube, L. C.; Caldas, S. S.; Soares, K. L.; Primel, E. G.; Microchim. Acta 2015, 182, 1765.

5. Montagner, C. C.; Vidal, C.; Acayaba, R. D.; Quim. Nova 2018, 40, 1094.

6. Gracia-Lor, E.; Martínez, M.; Sancho, J. V.; Peñuela, G.; Hernández, F.; Talanta 2012, 99, 1011.

7. Lei, M.; Zhang, L.; Lei, J.; Zong, L.; Li, J.; Wu, Z.; Wang, Z.; BioMed Res. Int. 2015, 2015, 12.

8. Ebele, A. J.; Abdallah, M. A.-E.; Harrad, S.; Emerging Contam. 2017, 3,1 .

9. Imo, S. T.; Sheikh, M. A.; Hirosawa, E.; Oomori, T.; Tamaki, F.; Int. J. Environ. Sci. Technol. 2007, 4, 1.

10. Caldas, S. S.; Bolzan, C. M.; Guilherme, J. R.; Silveira, M. A.; Escarrone, A. L.; Primel, E. G.; Environ. Sci. Pollut. Res. 2013, 20,5855 .

11. Jardim, W. F.; Montagner, C. C.; Pescara, I. C.; Umbuzeiro, G. A.; Di Dea Bergamasco, A. M.; Eldridge, M. L.; Sodré, F. F.; Sep. Purif. Technol. 2012, 84, 3.

12. Kuster, M.; Azevedo, D. A.; de Alda, M. J. L.; Aquino Neto, F. R.; Barceló, D.; Environ. Int. 2009, 35, 997.

13. Sodré, F. F.; Locatelli, M. A. F.; Jardim, W. F.; Water, Air, Soil Pollut. 2009, 206, 57.

14. Sodré, F. F.; Pescara, I. C.; Montagner, C. C.; Jardim, W. F.; Microchem. J. 2010, 96, 92.
15. Ministério da Saúde; Relação Nacional de Medicamentos Essenciais, RENAME 2017; Ministério da Saúde, Secretaria de Ciência, Tecnologia e Insumos Estratégicos, Departamento de Assistência Farmacêutica e Insumos Estratégicos: Brasília, 2017. Available at http://bvsms.saude.gov.br/bvs/publicacoes/ relacao_nacional_medicamentos_rename_2017.pdf, accessed in October 2017.

16. http://agrofit.agricultura.gov.br/agrofit_cons/principal_agrofit_ cons, accessed in August 2018.

17. Burns, M. D. M.; Garcia, A. M.; Vieira, J. P.; Bemvenuti, M. A.; Marques, D. M. L. M.; Condini, V.; Neotrop. Ichthyol. 2006, 4, 69.

18. Albertoni, E. F.; Palma-Silva, C.; Trindade, C. R.; Furlanetto, L. M.; Rev. Bras. Rec. Hidr. 2017, 22, DOI: 10.1590/23180331.011716082.

19. SANTE/11813/2017: Guidance Document on Analytical Quality Control and Method Validation Procedures for Pesticides Residues Analysis in Food and Feed; European Commission, 2017. Available at https://ec.europa.eu/food/sites/food/files/ plant/docs/pesticides_mrl_guidelines_wrkdoc_2017-11813. pdf, accessed in June 2017.

20. Mendonça, J. S.; Vieira, L. G.; Valdes, S. A. C.; Vilca, F. Z.; Tornisielo, V. L.; Santos, A. L. Q.; Ecotoxicology 2016, 25, 594.

21. Demoliner, A.; Caldas, S. S.; Costa, F. P.; Gonçalves, F. F.; Clementin, R. M.; Milani, M. R.; Primel, E. G.; J. Braz. Chem. Soc. 2010, 21, 1424.

22. Loos, R.; Tavazzi, S.; Paracchini, B.; Canuti, E.; Weissteiner, C.; Anal. Bioanal. Chem. 2013, 405, 5875.

23. Bonansea, R. I.; Amé, M. V.; Wunderlin, D. A.; Chemosphere 2013, 90, 1860.

24. Maldaner, L.; Jardim, I.; Talanta 2012, 100, 38.

25. Rocha, A. A.; Monteiro, S. H.; Andrade, G. C. R. M.; Vilca, F. Z.; Tornisielo, V. L.; J. Braz. Chem. Soc. 2015, 26, 2269.

26. Smalling, K. L.; Kuivila, K. M.; Orlando, J. L.; Phillips, B. M.; Anderson, B. S.; Siegler, K.; Hunt, J. W.; Hamilton, M.; Mar. Pollut. Bull. 2013, 73, 144.

27. Rodrigues, E. T.; Pardal, M. Â.; Gante, C.; Loureiro, J.; Lopes, I.; Environ. Pollut. 2017, 221, 150.

28. Kahle, M.; Buerge, I. J.; Hauser, A.; Müller, M. D.; Poiger, T.; Environ. Sci. Technol. 2008, 42, 7193.

29. Huang, Q.; Yu, Y.; Tang, C.; Peng, X.; J. Chromatogr. A 2010, $1217,3481$.

30. Caldas, S. S.; Demoliner, A.; Primel, E. G.; J. Braz. Chem. Soc. 2009, 20, 125.

31. Cerqueira, M. B. R.; Caldas, S. S.; Primel, E. G.; J. Chromatogr. A 2014, 1336, 10.

32. Altenhofen, S.; Nabinger, D. D.; Wiprich, M. T.; Pereira, T. C. B.; Bogo, M. R.; Bonan, C. D.; Chemosphere 2017, 180, 483.

33. Toni, C.; Ferreira, D.; Kreutz, L. C.; Loro, V. L.; Barcellos, L. J. G.; Chemosphere 2011, 83, 579. 
34. Caldas, S.; Primel, E.; Zanella, R. In Herbicides and Environment; Kortekamp, A., ed.; IntechOpen: Rijeka, Croatia, 2011, ch. 23.

35. Cabrera, L. C.; Caldas, S. S.; Rodrigues, S.; Bianchini, A.; Duarte, F. A.; Primel, E. G.; J. Braz. Chem. Soc. 2010, 21, 2347.

36. Munaron, D.; Tapie, N.; Budzinski, H.; Andral, B.; Gonzalez, J.-L.; Estuarine, Coastal Shelf Sci. 2012, 114, 82.

37. Köck-Schulmeyer, M.; Ginebreda, A.; Postigo, C.; Garrido, T.; Fraile, J.; de Alda, M. L.; Barceló, D.; Sci. Total Environ. 2014, 470-471, 1087.

38. Castro, Í. B.; Westphal, E.; Fillmann, G.; Quim. Nova 2011, 34, 1021.

39. Dominguez, L. A.; Caldas, S. S.; Primel, E. G.; Fillmann, G.; J. Braz. Chem. Soc. 2014, 25, 1302.

40. Battaglin, W. A.; Furlong, E. T.; Burkhardt, M. R.; Peter, C. J.; Sci. Total Environ. 2000, 248, 123.

41. Golombieski, J. I.; Sutili, F. J.; Salbego, J.; Seben, D.; Gressler, L. T.; da Cunha, J. A.; Gressler, L. T.; Zanella, R.; Vaucher, R. A.; Marchesan, E.; Baldisserotto, B.; Ecotoxicol. Environ. Saf. 2016, 128, 91.

42. Pareja, L.; Martínez-Bueno, M. J.; Cesio, V.; Heinzen, H.; Fernández-Alba, A. R.; J. Chromatogr. A 2011, 1218, 4790.

43. Chen, Z.-F.; Ying, G.-G.; Lai, H.-J.; Chen, F.; Su, H.-C.; Liu, Y.-S.; Peng, F.-Q.; Zhao, J.-L.; Anal. Bioanal. Chem. 2012, 404, 3175.

44. Hurtado-Sánchez, M. C.; Romero-González, R.; RodríguezCáceres, M. I.; Durán-Merás, I.; Frenich, A. G.; J. Chromatogr. A 2013, 1305, 193.

45. Huntscha, S.; Singer, H. P.; McArdell, C. S.; Frank, C. E.; Hollender, J.; J. Chromatogr. A 2012, 1268, 74.

46. Grützmacher, D. D.; Grützmacher, A. D.; Agostinetto, D.; Loeck, A. E.; Roman, R.; Peixoto, S. C.; Zanella, R.; Rev. Bras. Eng. Agric. Ambient. 2008, 12, 632.

47. Primel, E. G.; Milani, M. R.; Demoliner, A.; Niencheski, L. F. H.; Escarrone, A. L. V.; Int. J. Environ. Anal. Chem. 2010, 90, 1048.

48. European Commission; Council Directive 98/83/EC of 3 November 1998 on the Quality of Water Intended for Human Consumption; Official Journal of the European Communities, 1998. Available at https://eur-lex.europa.eu/legal-content/EN/ TXT/?uri=CELEX\%3A31998L0083, accessed in August 2018.

49. European Commission; Directive 2013/39/EU of the European Parliament and of the Council of 12 August 2013 Amending Directives 2000/60/EC and 2008/105/EC as Regards Priority
Substances in the Field of Water Policy; Official Journal of the European Communities, 2013. Available at https://eur-lex. europa.eu/legal-content/PT/TXT/PDF/?uri=CELEX:32013L0 039\&from=EN, accessed in August 2018.

50. Albuquerque, A.; Ribeiro, J.; Kummrow, F.; Nogueira, A.; Montagner, C.; Umbuzeiro, G.; Environ Sci.: Processes Impacts 2016, 18, 779 .

51. Montagner, C. C.; Umbuzeiro, G. A.; Pasquini, C.; Jardim, W. F.; Environ Sci.: Processes Impacts 2014, 16, 1866.

52. Silveira, M. A. K.; Caldas, S. S.; Guilherme, J. R.; Costa, F. P.; Guimarães, B. S.; Cerqueira, M. B. R.; Soares, B. M.; Primel, E. G.; J. Braz. Chem. Soc. 2013, 24, 1385.

53. Al-Odaini, N. A.; Zakaria, M. P.; Yaziz, M. I.; Surif, S.; J. Chromatogr. A 2010, 1217, 6791.

54. Czarczyńska-Goślińska, B.; Zgoła-Grześkowiak, A.; JeszkaSkowron, M.; Frankowski, R.; Grześkowiak, T.; J. Environ. Manage. 2017, 204, 50.

55. Li, W.; Gao, L.; Shi, Y.; Wang, Y.; Liu, J.; Cai, Y.; Sci. Total Environ. 2016, 539, 262.

56. Casas Ferreira, A. M.; Möder, M.; Fernández Laespada, M. E.; Anal. Bioanal. Chem. 2011, 399, 945.

57. Pedrouzo, M.; Borrull, F.; Marcé, R. M.; Pocurull, E.; J. Chromatogr. A 2009, 1216, 6994.

58. Yamamoto, H.; Tamura, I.; Hirata, Y.; Kato, J.; Kagota, K.; Katsuki, S.; Yamamoto, A.; Kagami, Y.; Tatarazako, N.; Sci. Total Environ. 2011, 410-411, 102.

59. Soni, M.; Taylor, S.; Greenberg, N.; Burdock, G.; Food Chem. Toxicol. 2002, 40, 1335.

60. Pedersen, K. L.; Pedersen, S. N.; Christiansen, L. B.; Korsgaard, B.; Bjerregaard, P.; Pharmacol. Toxicol. 2000, 86, 110.

61. Lacey, C.; Basha, S.; Morrissey, A.; Tobin, J. M.; Environ. Monit. Assess. 2012, 184, 1049.

62. Lima, A. B.; Chaves, S. C.; Silva, L. M.; Pereira, P. F.; Richter, E. M.; Santos, W. T. P.; Quim. Nova 2013, 36, 1296.

63. Papageorgiou, M.; Kosma, C.; Lambropoulou, D.; Sci. Total Environ. 2016, 543, 547.

64. Luque-Espinar, J. A.; Navas, N.; Chica-Olmo, M.; CantareroMalagón, S.; Chica-Rivas, L.; J. Hydrol. 2015, 531, 612.

Submitted: May 17, 2018

Published online: August 15, 2018 